\title{
The Effects of Monetary Variables on the Growth of Small and Medium Industry in Aceh Province
}

\author{
Ade Habya Fijay, Vivi Silvia*, Chenny Seftarita \\ Department of Economics, Faculty of Economics and Business, Syiah Kuala University, Darussalam, Banda Aceh, Indonesia \\ *Corresponding author email: vivisilvia@unsyiah.ac.id
}

\begin{abstract}
This study aims to analyze the effect of inflation, bank credit, and SMI investment on the growth of small and medium industries in Aceh Province. This study uses panel data consisting of 23 districts/cities in Aceh Province during the period 2014 to 2020. The analysis model used in this study is a panel data regression model. The results found in this study are variables that have a significant effect on the growth of SMIs in Aceh Province are inflation and investment in SMIs. Meanwhile, the banking credit variable has not had a statistically significant effect on the growth of SMIs. The inflation variable has a negative and significant effect on the growth of SMIs so that uncontrolled inflation will have a negative impact on the growth of SMIs. Meanwhile, SMI investment has a positive and significant impact on the growth of SMIs so that various targeted investment policies are needed so that they can support the development of SMIs in Aceh Province.
\end{abstract}

Keywords: Small and Medium Industries, Inflation, Investment and Banking Credit

\section{Introduction}

After the global monetary crisis, including Indonesia in 1997, small and medium industries (SMI) have the advantage of being highly resistant to the effects of the global crisis. SMI also helps accelerate the rate of economic growth of a country because this sector absorbs a lot of labor, because in general the workforce needed for small and medium industries does not require certain educational qualifications in carrying out their business activities (Andriyani et al., 2021; Rahmayati, 2021). SMI plays a very significant role for the national economy, in addition to the fact that small and medium industries are industrial scales that can withstand economic storms (Berry et al., 2021; Indris and Primiana, 2005).

The Central Statistics Agency (2019) stated that the industrial sector contributed greatly to the Indonesian economy in 2018, reaching 2,947.3 trillion or equivalent to $19.82 \%$ of the total GRDP achieved by Indonesia. The magnitude of this contribution is inseparable from the support provided by the production growth of the large and medium manufacturing industry sector which reached $4.45 \%$ and the micro and small manufacturing industry which reached 6.88 percent in the first quarter of 2018. The high production in the industrial sector is one of the reasons for this. the large role of small and medium industries that can absorb up to $65 \%$ of the total number of workers in the industrial sector (Ministry of Industry, 2019).

Various steps have been taken by the government in order to strengthen small and medium industries in the Indonesian economy, such as technological progress, security in running their business, and so on. The Indonesian Information and Communication Technology Creative Industry Society (2018) noted that the number of startups in Indonesia in 2018 reached 992 units but was still centered in the Greater Jakarta area.

In addition, the difference between small and medium industries compared to large-scale industries is their flexibility and high adaptability in the face of rapid market changes. This also applies in the province of Aceh where the number of small and medium industries tends to increase every year. Based on data from the Central Statistics Agency for Aceh Province (2021), the share given by the industrial sector to the GRDP in Aceh Province is 6.06 trillion rupiah in 2020 with a share of $4.56 \%$ of the total GRDP of Aceh Province.

However, the development of the industrial sector in Aceh Province is still not optimal. This is illustrated by the GRDP growth rate of the industrial sector where in the last 5 years only in 2018 experienced growth of $8.26 \%$, the rest of this sector received a negative rate and even reached $-5.84 \%$ in 2016 . This phenomenon is getting worse. exacerbated by the occurrence of the covid-19 pandemic in 2020 so that the growth rate of this sector continues to 
depreciate to reach $-4.43 \%$ (Aceh Province Central Statistics Agency, 2021). This can illustrate the importance of developing the industrial sector for the better given the high number of workers that can be absorbed by the sector.

Many factors affect the growth and development of small and medium industries. Some of them are inflation, bank credit, and small and medium industry investment. These three factors were chosen in order to see the influence of the monetary sector on the development of small and medium industries in Aceh Province. This factor is also a factor that is very attached to the industry and the characteristics of the industry in Aceh Province. Inflation indirectly has a very close relationship to the development of small and medium industries. Meanwhile, banking credit and small and medium industries investment are closely related to the characteristics of the industry in Aceh Province which still relies on sources of capital outside of its own ownership due to the condition of the majority of the population of Aceh Province which is still relatively poor so that it is constrained by capital in running the industry (Faiziah and Sofyan, 2014).

Haseeb et al. (2019) in her research suggests that the inflation rate has a significant negative effect on industrial growth. Even the correlation produced by the two variables reaches $98.7 \%$, so that the relationship between these variables is very close. Better handling of the inflation rate during the COVID-19 pandemic is urgently needed given the magnitude of the influence inflation has on industrial development in an area, including Aceh Province.

Table 1. Growth in the Number of SMI, Inflation, Growth in Banking Loans, and Growth in SMIs Investment in Aceh Province for the 2015-2020 Period.

\begin{tabular}{ccccccc}
\hline Indicator & $\mathbf{2 0 1 5}$ & $\mathbf{2 0 1 6}$ & $\mathbf{2 0 1 7}$ & $\mathbf{2 0 1 8}$ & $\mathbf{2 0 1 9}$ & $\mathbf{2 0 2 0}$ \\
\hline$(1)$ & $(2)$ & $(3)$ & $(4)$ & $(5)$ & $(6)$ & $(7)$ \\
\hline Number of SMI & 25.53 & 39.94 & 0.00 & 9.25 & 20.75 & 7.34 \\
Inflation & 1.53 & 3.95 & 4.25 & 1.84 & 1.69 & 3.59 \\
Banking Credit & 8.21 & 10.75 & 14.95 & 2.37 & 6.12 & -10.59 \\
SMIs Investment & 6.30 & 7.10 & 0.00 & 127.29 & -71.07 & 1.27 \\
\hline
\end{tabular}

Source: Department of Industry and Commerce (2021); Statistics of Aceh Province (2021); Bank Indonesia (2021)

Table 1 illustrates that there has been a slowdown in the growth of the number of SMIs where the highest growth of SMI occurred in 2016 which was $39.94 \%$. This is supported by an increase in the number of bank loans by $10.75 \%$. However, in 2020 there was a slowdown in growth to only $7.34 \%$, which was supported by inflation of 3.59 percent, a decrease in banking credit growth to $10.59 \%$ and an increase in investment which was only $1.27 \%$. This illustrates that the development of SMIs in Aceh is still not optimal. Industry involvement is one of the important factors that must be considered in designing work programs because the innovations produced by the industry continue to grow along with the increasingly complex needs of the community. Therefore, researchers are interested in conducting a study in order to identify how much influence the variables of inflation, bank credit, and SMI investment on the development of the number of small and medium industries in Aceh Province. This study contributes to find out the determinants factor that influence Small and Medium Enterprises investment, especially in Aceh Province, Indonesia. Also, identify the individual effect of studied variables.

\section{Literature Review}

The industrial sector is closely related to the production process, which is influenced by the employment of Lisani, et al. (2020). However, employment is influenced by the condition of the economy itself. Workers in the industrial sector tend to be influenced by inflation, the ability of the industry to develop itself through credit provided by banks and based on the value of investments issued by various parties.

The theory that supports this idea is the Philips curve where inflation, banking credit, and investment in small and medium-sized industries affect unemployment, where the reduction in labor results in a decrease in productivity so that it will slow down the development of small and medium-sized industries. However, the Philips curve does not have a long-term trade off, so modifications were made to the theory of the Philips curve so that it can explain unemployment conditions that have an impact on the development of the industry in long-term conditions where the unemployment rate is minimum but inflation is high. occurs tends to be stable or constant.

In general, industry is a processing activity from raw or semi-raw goods into finished goods that have added value. The industrialization strategy aims to achieve greater global competitiveness in the process of producing processed and manufacturing goods, namely by linking industrial processes and activities in the primary sector, both trade in goods and services (Chete et al., 2014).

Industrialization in Indonesia has started since the colonial period by the Dutch in 1830. Currently, industries that were already running were the food and beverage industry, textiles, and kretek cigarettes. This developed during the New Order era, changing the structure of the Indonesian economy from the agricultural sector to the industrial sector. Adrian (2018) in his research states that small and medium industries can be a solution to improving the Indonesian economy, which is better and more equitable but has a high level of challenges in the development of the sector which tends to be high due to the development of technology so that many SMIs are unable to keep up with these 
developments. SMI is a real solution for a region because MSMIs in the world employ about 63 percent of the workforce in the world (Berisha and Pula, 2015). Meanwhile, the role of small and medium industries that are incorporated into micro, small and medium enterprises (MSMIs) is not enough to be able to significantly encourage economic growth and increase people's income (Utami and Lantu, 2014). Whereas small and medium industries in Indonesia have been engaged in exports and imports so that the potential for small and medium industries to be able to contribute to the Indonesian economy becomes greater (Mashita et al., 2020).

In simple terms, inflation is an increase in the price of goods and services in a general and continuous period. The problem that occurs because of inflation is when we experience unexpected inflation and it is not matched by an adequate increase in people's income. If the amount of income does not increase along with the increase in the price of goods, then the purchasing power of each person will effectively decrease which can eventually cause the economy to slow down or stagnate. In addition, excessive inflation can also have an impact on retirement savings because it will reduce the exchange rate of the funds saved.

The theory that connects the inflation variable to industrial development is Keynes's theory through the IS-LM curve. The money supply will cause a movement towards inflation where inflation will make the real value of money decrease so that it will impose production costs on small and medium industries. Ajagbe (2012) suggests that the inflation rate has a direct impact on all the potential attractiveness of various strategies for industrial improvement.

One of the programs that is expected to be able to encourage the continued development of the industry through additional capital is the distribution of bank loans. The theory that explains the relationship between bank credit and the development of small and medium-sized industries is the economic theory of Harrod-Domar. The theory explains that additional capital will have an impact on economic growth through increased productivity.

The benefits of channeling bank credit are in order to increase business enthusiasm so that better and more competitive economic competition is created so that there is an even distribution of income and economic stabilization can be formed. Meanwhile, the profits generated can be shared both for banks, the government, the community, and entrepreneurs.

Another factor that has an impact on the development of SMIs is investment. Investment is an activity to gain future profits by committing to several funds or other resources at this time (Huda, 2013). The benefits of investing can increase aggregate demand, employment opportunities so as to increase overall national income. In addition, an increase in investment will have an impact on the addition of capital goods so that it will increase the amount of production. According to Sulistiawati (2012) said that continuous investment made by the community will increase economic activity and job opportunities. This of course also applies to SMIs so that increased investment will spur the growth of SMIs. Munzir et al. (2017) stated that government spending was able to boost economic growth through a stimulus for the development of small and medium industries. The investment issued can increase productivity so as to realize faster economic growth.

The theory that links investment and SMI growth is Keynes' economic theory. The ability of the government to be able to influence aggregate demand in order to approach the full employment position or commonly called Keynesian macro policy. The increase in economic growth $(\mathrm{Y})$ will occur in line with the increase in investment spending made by a business actor (I). The increase in economic growth is an empirical illustration that every business actor, including SMI, has increased production. This research is also supported by research conducted by Amaradiwakara and Gunatilake (2016) that the development of SMIs is constrained by the inability of capital and lack of access to new technology and the level of education which has a direct impact on the growth of SMIs.

To make it easier to understand the framework of thinking, the frame of mind is described in the Figure 1.

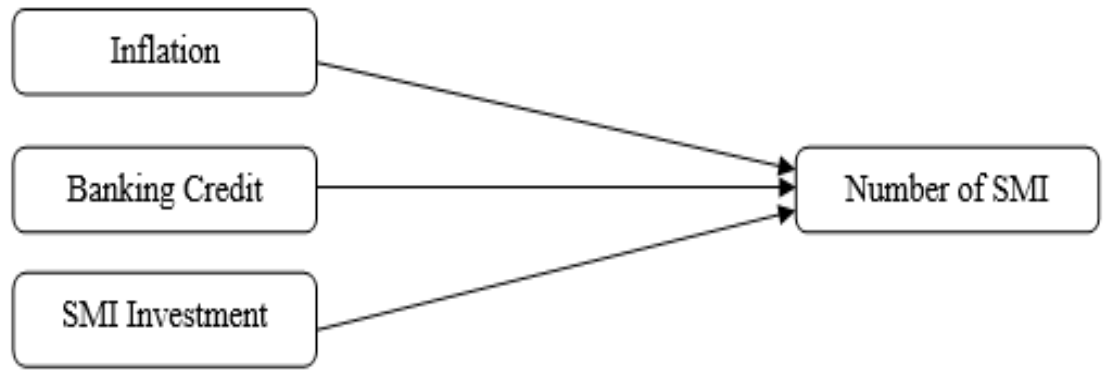

Figure 1. Research Framework

\section{Materials and Methods}

\subsection{Materials}

The variables that will be used in this study are 4 variables consisting of three independent variables and one dependent variable. The choice of the three independent variables is based on looking at the dominant variables on the 
growth of SMIs in terms of monetary variables. The variables in question are inflation, bank credit for SMIs, and investment for SMIs.

This research was conducted in 23 districts/cities in Aceh Province using time series secondary data for the period 2014-2020. The use of panel data in this study is intended to capture the influence that each individual has on the development of small and medium industries in Aceh Province. The data used in this study were sourced from the Central Bureau of Statistics of Aceh Province, the Aceh Industry and Trade Service and Bank Indonesia Representatives of Banda Aceh.

\subsection{Methods}

The data analysis was used in this research is descriptive and inferential statistics. Descriptive statistics aims to provide an overview of the data through graphs, tables, and images. The ways to explain data in a descriptive way is the use of tables and graphs appropriately so that the information conveyed can be channeled perfectly in accordance with statistical rules. Furthermore, the inferential statistics are to determine how much influence each independent variable has on the dependent variable using panel data regression.

\section{Results and Discussion}

Each region has a program to be able to improve its economy by encouraging the rate of economic growth while still paying attention to more equitable welfare. Various programs have been carried out to achieve this goal, one of which is the use of the industrial sector in order to support the economy of Aceh Province. Some of the developments carried out include establishing a Special Economic Zone and Aceh Industrial Estate which aims to carry out economic functions developed in an area that is superior in geo-economics and geostrategy in Aceh Province. The greater contribution made by the non-oil and gas industrial sector shows that Aceh Province has been able to rise after its glory by relying on various oil and gas sectors such as PT. Arun and so on to support the economy. The oil and gas sector industry tends to have limited resources so that with the improvement of the non-oil and gas industrial sector, it will bring new hope where the creative economy will rise with various perfect competitions so that it will be able to increase economic growth in Aceh Province.

Table 2. GRDP and Contribution of the Non-Oil and Gas Industry Sub-Sector in Aceh Province in 2020.

\begin{tabular}{ccc}
\hline Non-Oil and Gas Industry Sub-Sector & GRDP 2020 & Contribution \\
$(1)$ & $(2)$ & 51.72 \\
\hline Food and Beverage Industry & $3,161,699.39$ & 0.48 \\
Tobacco Processing Industry & $29,113.53$ & 0.34 \\
Textile and Apparel Industry & $20,588.07$ & 0.09 \\
Leather, Leather Goods and Footwear Industry & $5,649.27$ & 1.22 \\
goods from bamboo, rattan and similar & $74,387.55$ & \\
Industry of wood, goods made of wood and cork and woven & & 1.97 \\
Industry of Paper and Paper Goods; Printing and & $120,123.33$ & 32.05 \\
Reproduction of Recorded Media & & \\
Chemical, Pharmaceutical and Traditional Medicine & $1,958,879.32$ & 2.69 \\
Industry & & 4.49 \\
Industry of Rubber, Rubber and Plastic Goods & $164,495.19$ & 0.00 \\
Non-Metal Mineral Industry & $274,360.75$ & 0.43 \\
Base Metal Industry & - & \\
Industry of Metal Goods; Computers, Electronic Goods, & $26,202.45$ & 0.73 \\
Optics; and Electrical Equipment & & 0.40 \\
Machinery and Equipment Industry & $44,674.27$ & 3.28 \\
Transport Equipment Industry & $24,446.22$ & 0.12 \\
Furniture Industry & $200,544.52$ & $7,576.30$ \\
\hline
\end{tabular}

Source: Statistics of Aceh Province (2020)

Table 2 shows that the non-oil and gas industrial sector in Aceh Province in 2020 is dominated by only a few subsectors. Of the 15 non-oil and gas industry sub-sectors, only 2 sub-sectors provide a share of more than 10 percent, namely the food and drink industry sub-sector and the chemical, pharmaceutical and traditional medicine sub-sectors. The food and drink industry sub-sector dominate the non-oil and gas industry sector by contributing $51.72 \%$ or 
equivalent to 3.16 trillion rupiah. Furthermore, the sub-sector that provides the largest share is the chemical, pharmaceutical and traditional medicine industry sub-sector, which is $32.05 \%$ or equivalent to 1.96 trillion rupiah.

The next analysis is inferential analysis in the form of linear regression analysis of panel data which is used to see the effect given by the independent variables on the dependent variable in a study. The result of selecting the best model that has been done is that the best panel data regression model for analyzing this research is the fixed effects model.

The panel data regression model using a random effect model approach can be seen in Table 3 .

Table 3. Estimation Results of Panel Data Linear Regression Using Fixed Effect Model Approach

\begin{tabular}{lcccc}
\hline \multicolumn{1}{c}{ Variable } & Coefficient & Std. Error & t-Statistic & Prob. \\
\hline \multicolumn{1}{c}{1} & 2 & 3 & 4 & 5 \\
\hline Inflation & -153.96 & 39.3741 & -3.9102 & 0.0001 \\
Investment & $3.83 \mathrm{E}-07$ & $1.91 \mathrm{E}-07$ & 2.00353 & 0.0471 \\
Banking Credit & 0.00054 & 0.00029 & 1.88192 & 0.062 \\
\multicolumn{1}{c}{$\mathrm{C}$} & 1451.4 & 184.978 & 7.8463 & 0 \\
\hline R-squared & 0.75426 & & F-statistic & 16.5745 \\
Adjusted R-squared & 0.70875 & & Prob(F-statistic) & 0 \\
\hline
\end{tabular}

Statistically, the results of the former model are fit. This can be seen from the Prob value (F-statistic) of 0.000000 which is smaller than the alpha value of 0.05 . This situation explains that there is at least one independent variable that has a significant effect on the growth of SMIs in Aceh Province. In addition, the independent variable used can explain the variation in the value of the SMI growth of 75.43 percent.

Inflation variable that can describe price movements that occur in a period compared to the previous period has a negative and significant impact on the growth of SMIs in Aceh Province. This illustrates that every $1 \%$ increase in inflation will reduce the growth of SMIs by 154 units. This finding is in accordance with research conducted by Saraswati and Rastini (2013) which states that inflation will lead to an increase in operations and industrial raw materials so that it will reduce the ability of an industry to continue to produce so that it will reduce the number of SMIs that are able to survive.

Next is the SMI investment variable that has a positive and significant impact on the growth of SMIs in Aceh Province. Every 1 billion rupiah increase in SMI investment will increase the growth of SMI by 380 units. This is because increasing investment will encourage production growth which will increase the output of an industry. This increase will cause the supply of goods and services in the market to increase so that it will become a catalyst for the development of SMIs in a region. This is in accordance with research conducted by Zhu et al. (2020) which states that investment is able to encourage industrial growth when the investment is made in accordance with the prevailing economic conditions in an area.

The last variable that influences the growth of SMIs is bank credit. Statistically, SMI banking credit has a positive and significant impact on the growth of SMIs. Every 1 billion rupiah increase in bank credit can increase the growth of SMI by 1 unit. This is because credit is something that is not very familiar to small industries in Aceh Province so that only a few of the utilization of bank credit that can be channeled are absorbed. In addition, the study suggests that the high non-performing loans is the impact of many industries that are unable to survive in Aceh Province by using SMI banking credit.

The emergence of sharia banking policies implemented in Aceh Province is another factor why the absorption of bank credit tends to stagnate so that it has very little effect. The unequal distribution of information obtained by SMIs and the non-optimal transition of conventional banking to Islamic banking are the reasons for the stagnant absorption of bank credit.

\section{Conclusion}

Based on the results and discussion previously discussed, the conclusions given in this study are found that all variables used in this study affect the growth of SMIs, namely inflation, SMI investment, and bank credit. The inflation factor has a negative and significant effect on the growth of SMIs in Aceh Province. These results indicate that the inflation rate that has occurred in Aceh Province has hampered the growth of SMIs. Inflation that occurs can have an effect through rising prices for raw materials, operations, and labor so that any occurrence of inflation will aggravate the development of SMIs. The investment factor in SMI has a positive and significant effect on the growth of SMI in Aceh Province. This indicates that the given investment can be maximized by SMI entrepreneurs to be able to increase their production so that it will stimulate the increase of SMI in Aceh Province. The banking credit factor has a positive and significant effect on the growth of SMIs in Aceh Province. The effect given by this variable is smaller when compared to SMI investment. This is inseparable from the lack of interest of the Acehnese people to maximize capital through bank credit. The high level of non-performing loans and the complexity of applying for bank loans add to the reasons for the majority of SMIs not to apply for bank loans. 
Therefore, it is hoped that all authorized parties can accelerate the growth of SMIs in Aceh Province. This can be done by paying attention to the variables tested that affect the growth of SMIs, such as maintaining the inflation rate at a level that can be balanced by SMIs in Aceh Province. This aims, apart from ensuring that SMIs can continue to grow in producing goods, inflation can also be used as an indicator that people have a more equitable ability to own goods or services. This ability will cause more money in circulation resulting in inflation. Therefore, it is important for the government to be able to control the rate of inflation. In addition, it can also be done by increasing the level of investment that can be channeled to SMIs. Increased investment will stimulate productivity that can be achieved so that the resulting output will be greater. Helping SMIs to obtain investment is one of the policies that can be taken by the government. Either by inviting local and foreign investors to collaborate with the potential of SMIs that are owned between regions in Aceh Province.

Furthermore, by increasing the effectiveness of bank credit and educating SMIs to be able to take advantage of bank credit, especially sharia banking credit that has been applied in Aceh Province. Islamic banking credit obtained so that it can be used optimally by SMI actors in order to increase output to the maximum. The people of Aceh already have a mindset that conventional banking credit will only make it difficult for SMI actors because of the shadow of the level of credit that must be repaid. Therefore, the challenge of Islamic banking is to provide an understanding of the profit sharing offered by Islamic banking in Aceh Province.

\section{References}

Adrian, M. A. (2018). Empowerment Strategies of Micro, Small, Medium Enterprise (MSMIs) to Improve Indonesia Export Performance. International Journal of Economics, Business and Accounting Research (IJEBAR), 2(04), 50-60.

Amaradiwakara, A. U., \& Gunatilake, M. M. (2017). Factors affecting growth of small and medium enterprises in Sri Lanka. International Journal of Advanced Research, 3(2), 1805-1814.

Andriyani, D., Nailufar, F., Yurina, Y., Ratna, R., \& Rahmah, M. (2021). Analyzing the Sustainability of Micro, Small and Medium Enterprises during Covid-19 Pandemic in Bireuen Regency, Indonesia. International Journal of Business, Economics, and Social Development, 2(3), 119-126.

Ajagbe, F. A. (2012). Inflation and Small and Medium Enterprises Growth in Ogbomoso Area, Oyo State, Nigeria. Journal of Economics and Sustainable Development, 3(8), 167-171.

Berisha, G., \& Pula, J. S. (2015). Defining Small and Medium Enterprises: A Critical Review. Academic Journal of Business, Administration, Law and Social Science, 1(1), 17-28.

Chete, L. N., Adeoti, J. O., Adeyinka, F. M., \& Ogundele, O. (2014). Industrial development and growth in Nigeria: Lessons and challenges (No. 2014/019). WIDER working paper.

Faiziah, A., \& Sofyan. (2014). The Influence of the Number of Manpower, Exports, Investment and Banking Credit in the Agricultural Sector on the Gross Regional Domestic Product (GRDP) of the Agricultural Sector of Aceh Province. Jurnal Agrisep, 15(2), 36-44.

Haseeb, M., Zandi, G., Hartani, N. H., Pahi, M. H., \& Nadeem, S. (2019). Environmental analysis of the effect of population growth rate on supply chain performance and economic growth of Indonesia. Ekoloji, 28(107), 417-426.

Huda, M. (2013). Strategies, Performance, Sustainability and Competitiveness Model: Small and Medium Construction Services Industries in Indonesia. World Applied Sciences Journal, 25(8), 1186-1196.

Indris, S., \& Primiana, I. (2015). Internal and external environment analysis on the performance of small and medium industries SMEs in Indonesia. International journal of scientific \& technology research, 4(4), 188-196.

Lisani, N., Masbar, R., \& Silvia, V. (2020). Inflation-Unemployment Trade-Offs In ASEAN-10. Jurnal Ilmu Ekonomi, 9(2), 241256.

Mashita, J., Estiningsih, W., \& Koranti, K. (2020). The Effect of Small and Medium Micro Business Growth (SMIs) Toward Economic Growth in Jakarta. American Journal of Humanities and Social Sciences Research, 4(2), 183-186.

Munzir, Syechalad, M. N., \& Silvia, V. (2017). The Effect of Government Expenditures, Private Investment and Labor on Economic Growth in Pidie District. Sriwijaya International Journal of Dynamic Economics and Business, 1(4), 357-374.

Rahmayati, R. (2021). Competition Strategy In The Islamic Banking Industry: An Empirical Review. International Journal Of Business, Economics, And Social Development, 2(2), 65-71. 
Saraswati, P. E. P., \& Rastini, K. (2013). Pengaruh Investasi, Tenaga Kerja dan Inflasi Terhadap Nilai Produksi Pada Sektor Industri. Jurnal Ekonomi Pembangunan Universitas Udayana, 2(8), 367-372.

Sulistiawati, R. (2012). Pengaruh Investasi Terhadap Pertumbuhan Ekonomi dan Penyerapan Tenaga Kerja Serta Kesejahteraan Masyarakat di Provinsi di Indonesia. Jurnal Ekonomi Bisnis Dan Kewirausahaan, 3(1), $29-50$.

Utami, R. M., \& Lantu, D. C. (2014). Development Competitiveness Model for Small-Medium Enterprises among the Creative Industry in Bandung. Procedia - Social and Behavioral Sciences, 115(1), 305-323.

Zhu, Z., Ji, Q., Sun, L., \& Zhai, P. (2020). Oil price shocks, investor sentiment, and asset pricing anomalies in the oil and gas industry. International Review of Financial Analysis, 70, 101516. 